\title{
Assessment of Major Road Transportation Planning and Management for Commercial Transport in Urban Settlement
}

\author{
Adewuyi Gbola Kehinde*, Iyanda Gbemisola O \\ Department of Surveying and Geoinformatics, Faculty of Environmental Studies, The Polytechnic, Ibadan, \\ Nigeria.
}

*Corresponding Authors: Adewuyi Gbola Kehinde, Department of Surveying and Geoinformatics, Faculty of Environmental Studies, The Polytechnic, Ibadan, Nigeria.

\begin{abstract}
This study critically assesses the road transportation planning and management for commercial transport in Ibadan North Local Government Area, Oyo state, Nigeria using GIS approach. Field observation was carried out using surveying method while other data were collected through questionnaires and oral interviews. Hi-Target Differential Global Positioning System (DGPS) was used to acquire spatial data i.e. $(x, y, z)$ coordinates of garages, bus stops, traffic lights T-Junctions (road intersections). Four hundred (400) structured questionnaires was administered and distributed among the road users comprising of the commercial transporters and passengers in which three hundred and seventy (370) questionnaires were completed and returned. All data acquired in this study was obtained between the periods of month (Nov. to Dec., 2019). Further analysis was carried out using Hi-Target Geomatics Office (HGO), Global Navigation Satellite System (GNSS) Solution and IBM SPSS 20 Statistical Package for the social sciences for data processing and analysis, and ArcGIS 10.2.1 for graphic designs. The results of the study were presented in form of plans/maps, map queries, charts and frequency tables. Generally, from the study, it was observed that commercial road transportation still need Government intervention in the area of management though the response from the passengers as well the transporters on planning mostly agreed that the road are properly planned. Improper location of garages and bus stops along the routes which causes traffic congestion as a result of illegal parking, insufficient parking space, excessive pedestrian crossing, inadequate/malfunction of traffic light and others be given attention. It is hoped that this study will become the foundation for further study and research in the area to improve commercial road transportation planning and management in Ibadan North Local Government Area as well as the entire Ibadan metropolis.
\end{abstract}

Keywords: Road transportation, planning and management, Geographical Information System, traffic congestion.

\section{INTRODUCTION}

Roads are designed to serve different purposes, which can be referred to as a "functional classes" (Feng and Levison, 2006). Functional classification is the process by which streets and highways are grouped into classes according to the character of service they are intended to provide (Federal Highway Administration, 1997). Transportation and property are important in physical and economic development of towns and cities all over the world. Property and land values tend to increase in areas with expanding transportation networks, and increase less rapidly in areas without such improvements. Rapid and continued rise in housing and land prices are expected in cities with transportation improvements and rapid economic and population growth (Goldberg, 1970). The importance of transportation cannot be over-emphasized. Transportation centrally affects the relationship between physical space and society, and changes in transportation affect the organization of human activity in urban and regional space. It structures the built environment, spurs urban growth, as well as orders relationships among cities in a national urban system (Yago, 1983).

The importance of transportation to the economy of nations has been widely recognized. It has been argued that the level of transportation in a country is linked with the level of economic development of that country (Okoko, 2006). Transportation and land use planning decisions interacts, that is transport planning decisions affect land use development, and land use conditions affect transport activity as reported (Litman, 2015). He went on to investigates how some land use factors affect 
transport activity, including vehicle ownership, vehicle travel (vehicle trips and vehicle miles of travel or VMT), mode share (the portion of trips by different modes), active transport (walking and cycling), and therefore impacts on various planning issues such as traffic congestion, infrastructure costs, consumer costs, accident rates, physical fitness, and social equity objectives (Litman, 2015).

As one mode of transportation reached technological limits in extending urban space another takes its place (Berry and Garrison, 1958; Isard, 1960; Berry and Horton, 1970; Pred. 1974), and changes in urban physical structure are linked with transportation technology (Richardson, 1972). Transportation route is part of distinct development pattern or road network and mostly described by regular street patterns as an indispensable factor of human existence, development and civilization (Bailey et al., 2008). Road networks are observed in terms of its components of accessibility, connectivity, traffic density, level of service, compactness, and density of particular roads. Level of service is a measure by which the quality of service on transportation devices or infrastructure is determined, and it is a holistic approach considering several factors regarded as measures of traffic density and congestion rather than overall speed of the journey (Mannering et al., 2004). Developments of various transportation modes have become pivotal to physical and economic developments. Such modes include human porterage, railways, ropeways and cableways, pipelines, inland waterways, sea, air, and roads (Said and Shah, 2008). Urban areas have tendency to develop at nodal points in transport network and places with good road network will possess relative advantage over locations having poor network as stated (Wyatt, 1997).

Transportation planning is expressed as a co-operative process designed to foster involvement by all users of the system, such as the business community groups, environmental organization, the traveling public, freight operators and the general public, through a proactive participation process (Owolabi, 2016). Transportation Planning is the process of defining future policies, goals, investments, and designs to prepare for future needs to move people and goods to destinations. Transportation planning is the art and science of providing and managing transportation facilities in a manner that ensures an efficient movement of commuters and freights within a given spatial entity (Okoko 2006). Transportation is the act of transporting or the state of being transported; conveyance; often of people, goods, etc, while planning stands as the act of formulating of a course or courses of action, or of drawing up plans or programes for future events or activities (Didigwu and Fasina, 2015) . Geographic information system is a survey tool used to capture, store, query, analyze, manage and display geographic information/data (Kang-Tsung Chang, 2002). GIS transportation studies have employed both object-based and field-based data models to represent the relevant geographic data (Didigwu and Fasina, 2015).

Geographic Information Systems for Transportation Planning refers to the principles and applications of applying geographic information technologies to solve transportation problems (Didigwu, 2010). The capabilities of GIS have improved over the past three decades, and GIS now provide a wide range of tools for data management and analysis. In the early 1990s, GIS added specific tools for linear data management of transportation data that has proved to be extremely successful among transportation organizations (Sutton et al., 2004). These capabilities enable transit agencies to geo-reference their bus routes, stops, time points, and other features to a digital street centerline file, and keep all these data in synch (Sutton et al., 2004). Federal, state and local agencies are using GIS information to develop transportation policy and planning (Gupta et al., 2003). Centralized traffic control room can be made use of, to effectively manage the traffic. Information about the number of vehicles on each road, where there are jams and alternative roads can be displayed on electronic signboards installed at important traffic road junction (Didigwu and Fasina, 2015). Their research further stated that all important data like the number of vehicles on each road, information about the roads where there are jams and the details of alternative roads that can be taken can be displayed on huge electronic sign boards that can be installed at important traffic junctions, roads and even on the internet (Didigwu and Fasina, 2015). As vehicles along the roads are increasing day by day on our major roads in the study area as well as the entire Ibadan metropolis, the challenges of ineffective road transportation planning and management keep increasing and the available land to use for constructing new roads pose a big problem thereby making planning and managing a difficult task. Therefore, there arises the need to assess commercial road transportation planning and management in Ibadan North Local Government Area, Oyo state, Nigeria using GIS approach. 


\section{THE STUDY AREA}

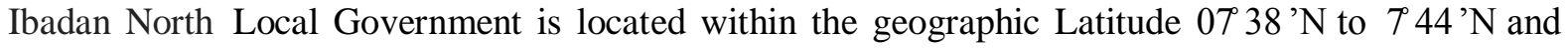
geographic Longitude $03^{\circ} 47 \mathrm{E}$ to $03^{\circ} 59^{\circ} \mathrm{E}$ It covers a total land area of about $27 \mathrm{~km}^{2}$ with a population of about 306,795 as at the 2006 census. By the Nigeria population growth rate of $2.553 \%$ according to CIA World fact book (2013) and the projection formula (Mehta, 1996) as $\mathrm{Pt}=\mathrm{Po}(1+(\mathrm{R}) \mathrm{n})$ where $\mathrm{Pt}$ $=$ Projected population, $\mathrm{Po}=$ Base year population $\mathrm{R}=$ Annual growth rate $(2.553 \%) \mathrm{n}=$ Time interval, then the projected population of Ibadan North Local Government Area as at 2019 was calculated as 408,617 people. It's headquarter is located at Agodi Gate Ibadan. The Local Government is surrounded by higher institution of learning such as University of Ibadan, founded in 1948, The Polytechnic, Ibadan founded in 1970 and the Nigeria Institute of Social and Economic Research (NISER).it is a center of commercial activities. The major mode of transportation in the study area is by road. Figure 1 describes the location of the study area.

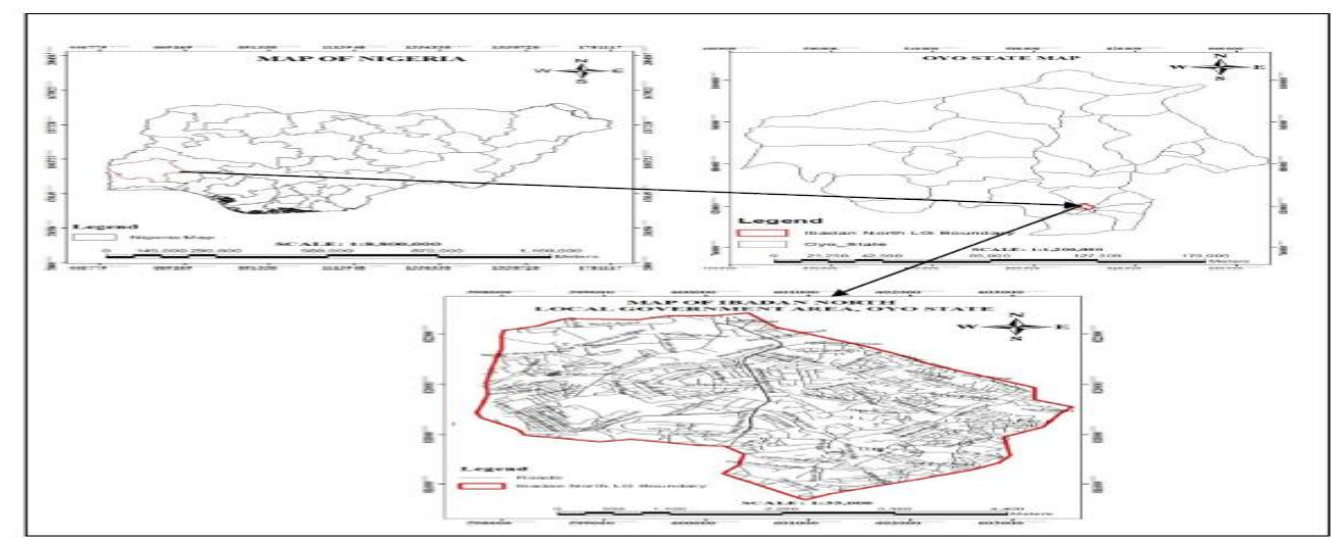

Figure1. Map of the study area

\section{MATERIALS AND METHODS}

According to Kothari (2004), research methodology described the various steps, guidelines and measures by which data for a particular study are sourced, collected, processed, and analyzed, with a view of coming up with findings that will help in achieving research goal. For the purpose of this study, both primary and secondary data were used. The primary data sources include the field surveying method using Hi-Target DGPS in acquiring the coordinates ( $\mathrm{x}, \mathrm{y}$ and $\mathrm{z}$ ). Questionnaires were administered to Transporters, Passengers/Passerby etc. and Oral interview. Secondary data source involved the related journals, conference proceedings, seminars/workshops, Books etc., Ibadan road map used for spatial location of garages, sub-garages, bus stops, T-junctions, traffic light and coordinate of control point use for the study orientation was obtained from Oyo State Secretariat Agodi Ibadan.

\subsection{Methods of Data Acquisition}

The data acquire for this study includes data on questionnaires administered, oral interview, vehicle counting, use of DGPS equipment, travel time, travel speed, cost of transport, population density, road width and setbacks. Questionnaires were designed for the purpose of getting information about commercial road transporters on both major and minor roads and information regarding all issues relating to commercial road transportation planning and management in the study area. Four hundred (400) questionnaires were administered randomly among the road users in Ibadan North Local Government, comprising transporters and passengers. Out of 400 questionnaires distributed, 370 were duly completed and returned. The questionnaires that relates directly to all day to day experience were designed for passengers (hawkers, passer-by, office workers etc.), transporters (Car drivers, Bus drivers, Motorcycle riders, Tricycle riders). The mode of collecting the respondent responses was instant collection.

A hi-target differential GPS operating in static mode was utilized for the coordinate determination of standard garages, sub-garages and bus stops, T-junctions and traffic lights along the major routes within Ibadan North Local Government. The route under the study were; Ojoo-Mokola, BodijaSecretariat, Gate-Bashorun, Total Garden-Gate, Gate-Beere, Secretariat-Total garden, Gate-Mokola, 
Sango-Gate roads. Time travel was carried out in order to determine the time taken from a specific location to another within the study area. Stop watch was used for timing for better accuracy.

The speed estimation was done to determine the Average Speed Estimation of vehicles in the study area using vehicle speedometer. Survey on cost of transport on four (4) major means of transportation (i.e. Car, Buses, Tricycles and Motorcycles) was done to know the cost of the trip for passengers from a specific garage or bus stop to their respective destination. Also, the Population of people transported daily was done in order to know the population of people moving from each Garage/bus stop to their respective destinations using counting of total passengers per trip. The manual counting of vehicles (Car, Tricycle, Motorcycle, Buses) at each garage within the study area was done. The number of Traffic Lights and road intersection per each route was obtained during the field observation. The road width and setback specification for major highways, main roads and minor roads, was acquired from the ministry of works and housing Oyo State to compare the obtained data from the field during field observation. Steel tape was used to measure the road width and setbacks along each route.

Table1. Coordinate of the control point used

\begin{tabular}{|l|l|l|l|}
\hline Point identity & Northing (Y) & Easting (X) & Height \\
\hline YZN 364 & 820651.379 & 599156.600 & 243.144 \\
\hline
\end{tabular}

Source: Office of the Surveyor General, Oyo State

Table2. Specification for roads width and setbacks

\begin{tabular}{|l|l|l|l|l|l|}
\hline Major highways & Setback & Main roads & Setback & Minor roads & Setback \\
\hline $14 \mathrm{metres}$ & $15 \mathrm{metres}$ & $9 \mathrm{metres}$ & $10 \mathrm{metres}$ & $7 \mathrm{metres}$ & 3 metres \\
\hline
\end{tabular}

Source: FERMA, Oyo state.

\subsection{Data Processing}

The data acquired with hi-target DGPS receiver was downloaded using (HGO) Hi-target Geomatics Office and the data was processed with the same software which converts it to Rinex data. Also (GNSS) Global Navigation Satellite System solution software was used to convert the Rinex data to final coordinate (x, y).
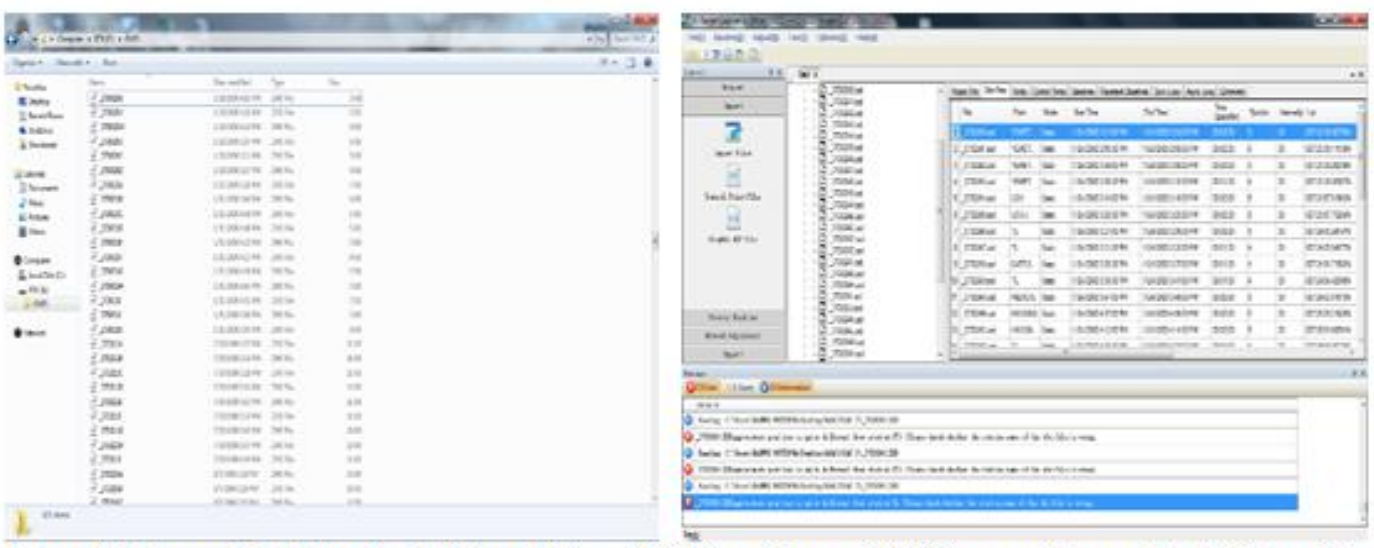

Figure 2. Ephemeris data downloaded from hi-target DGPS receiver and HGO process the raw data in Rinex data.
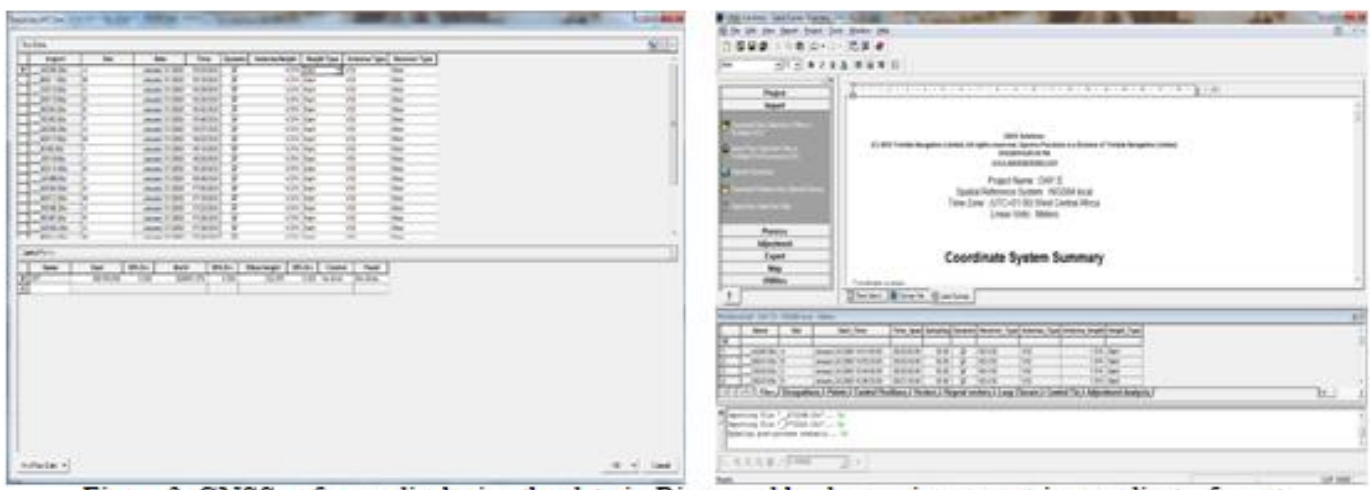

Figure 3. GNSS software displaying the data in Rinex and land overview report in coordinate format. 
Assessment of Major Road Transportation Planning and Management for Commercial Transport in Urban Settlement

Table3. Sample result of final processed coordinate of DGPS data for Bus stops and Garages

\begin{tabular}{|c|c|c|c|c|c|}
\hline \multicolumn{6}{|l|}{ Bus Stops } \\
\hline Location & Easting (m) & Northing (m) & Location & Easting (m) & Northing (m) \\
\hline ST. Rita & 596878.330 & 820313.498 & Ajibade & 598703.052 & 819535.829 \\
\hline Oluseyi & 595942.290 & 820141.480 & Ore Meji & 598538.375 & 819375.560 \\
\hline Olopo Mewa & 596089.998 & 820149.798 & Corner & 599260.683 & 816054.141 \\
\hline Aro Meta & 596545.128 & 820250.200 & Adeoyo & 599611.392 & 816672.487 \\
\hline Poly & 598574.938 & 821177.911 & Iyana Sapati & 599312.726 & 816479.350 \\
\hline Elewure & 598999.617 & 820331.521 & Agbadagbudu & 599324.593 & 816720.370 \\
\hline Iyana Bodija & 598949.632 & 820186.685 & \multirow{2}{*}{ Gate } & 601389.205 & 817581.283 \\
\hline Leventis & 598813.120 & 819887.245 & & 596906.406 & 820296.962 \\
\hline \multicolumn{6}{|l|}{ For Garages } \\
\hline Location & Easting (m) & Northing (m) & & & \\
\hline Bodija & 600628.650 & 821808.349 & Eleyele & 594811.853 & 820249.986 \\
\hline Sango & 599197.804 & 820631.239 & & & \\
\hline
\end{tabular}

Database was created using IBM SPSS 20 (Statistical package for the social sciences) in order to analyse the results of the questionnaires duly completed and returned.
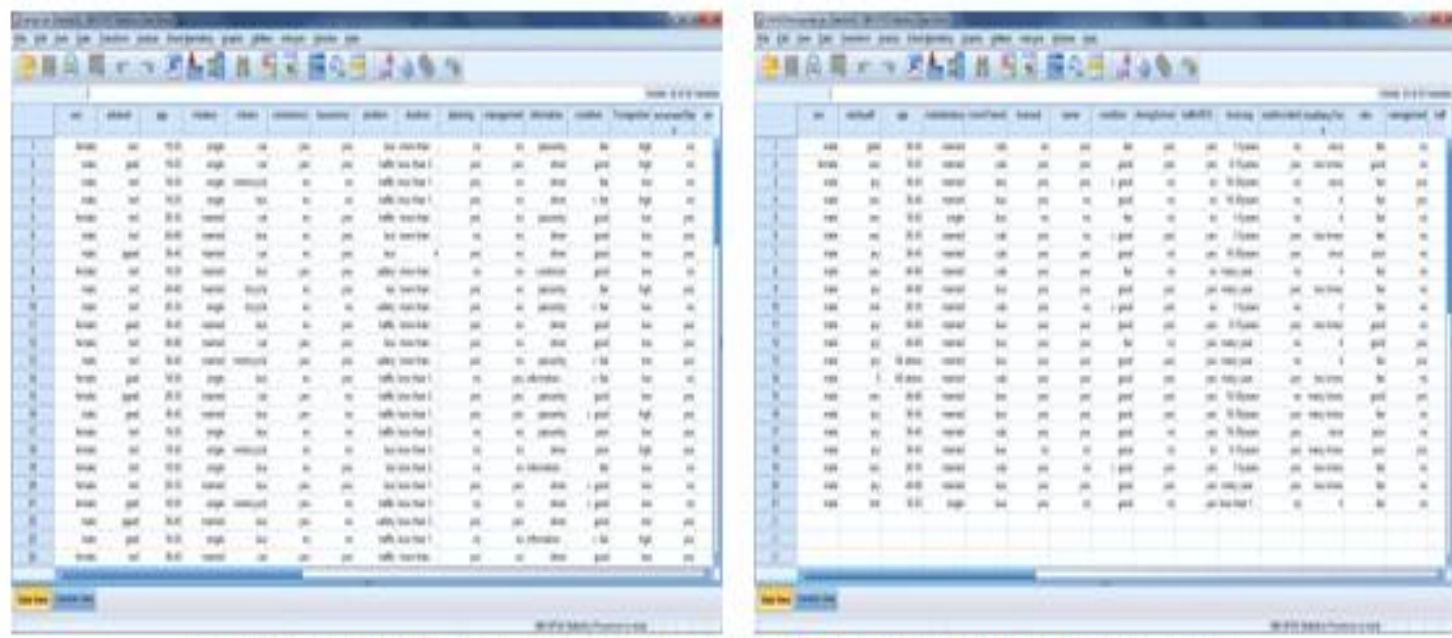

Figure 4. Database creation for the questionnaires (For passengers and transporters)

\section{RESULTS AND DISCUSSION}

Analyses were carried out on the returned questionnaires to understand the trends of responses concerning commercial road transportation planning and management and other data acquired for the study. The result of the analysis showed that out of seventy (70) questionnaires that was distributed at Bodija, only sixty-six (66) were returned. Ninety-one (91) were distributed at Sango and eighty-five was returned. Seventy-nine (79) were distributed at Gate and seventy-three (73) was returned. Sixty (60) were distributed at Mokola and fifty-three (53) was returned. Fifty (50) were distributed at Beere and forty-four (44) was returned. Fifty (50) were distributed at Eleyele while forty-nine (49) were returned (see Table 4, figure 5). Table 5-14 presents the various analyses of the results and Figure 6-9 presents various maps in relation to the study. Figure 10 presents the chart of proximity of bus stops and Figure 11-13 presents the queries.

Table 4. Result of the Analysis of Questionnaire Distributed and Returned

\begin{tabular}{|l|l|l|l|}
\hline S/N & Location Name & Distributed Questionnaires & Returned Questionnaires \\
\hline $\mathbf{1}$ & Bodija & 70 & 66 \\
\hline $\mathbf{2}$ & Sango & 91 & 85 \\
\hline $\mathbf{3}$ & Gate & 79 & 73 \\
\hline $\mathbf{4}$ & Mokola & 60 & 53 \\
\hline $\mathbf{5}$ & Beere & 50 & 44 \\
\hline $\mathbf{6}$ & Eleyele & 50 & 49 \\
\hline & Total & 400 & 370 \\
\hline
\end{tabular}


Assessment of Major Road Transportation Planning and Management for Commercial Transport in Urban Settlement

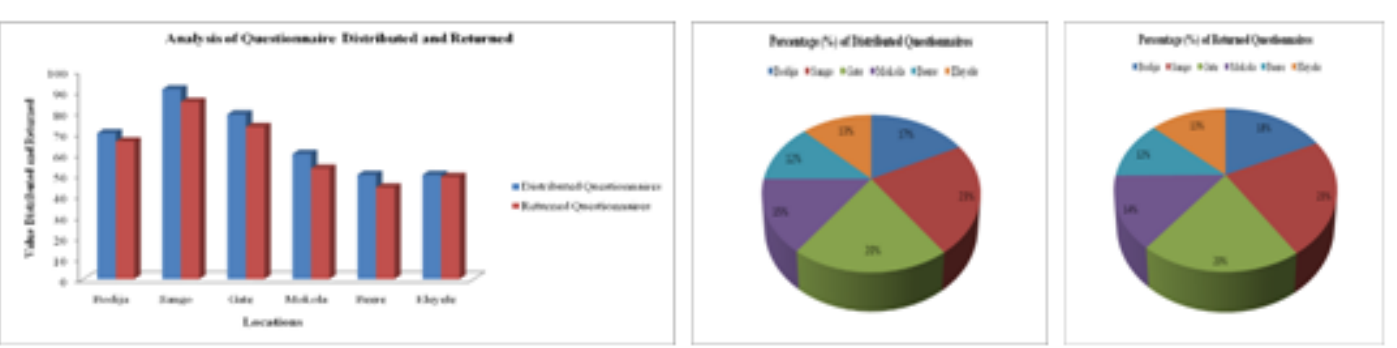

Fig. 5 Chart showing Questionnaire Distributed and Retumed across category and Retumed in Percentage

Table5. Result of the Analysis of Questionnaire Designed for Transporters

\begin{tabular}{|c|c|c|c|c|c|}
\hline Sex & Frequency & Percentage & $\begin{array}{l}\text { Are you a licensed } \\
\text { driver? }\end{array}$ & Frequency & Percentage \\
\hline Male & 130 & 94.9 & Yes & 124 & 90.5 \\
\hline Female & 7 & 5.1 & No & 13 & 9.5 \\
\hline Total & 137 & 100 & Total & 137 & 100 \\
\hline \multicolumn{3}{|c|}{ Educational Qualification } & \multicolumn{3}{|c|}{ How many minutes do you drive to your destination? } \\
\hline Primary & 40 & 29.2 & $5 \operatorname{mins}$ & 17 & 12.4 \\
\hline Secondary & 63 & 46 & 19mins & 22 & 6.1 \\
\hline Tertiary & 15 & 10.9 & $15 \mathrm{mins}$ & 22 & 16.1 \\
\hline Graduate & 13 & 9.5 & $20 \mathrm{mins}$ & 28 & 20.4 \\
\hline Post graduate & 6 & 4.4 & Above 20mins & 48 & 35 \\
\hline Total & 137 & 100 & Total & 137 & 100 \\
\hline \multicolumn{3}{|l|}{ Age Group } & \multicolumn{3}{|c|}{$\begin{array}{l}\text { For how long have you been in this commercial } \\
\text { transport? }\end{array}$} \\
\hline $18-25$ & 0 & 7.3 & less than 1 year & 8 & 5.8 \\
\hline $26-35$ & 35 & 25.5 & 1-5years & 38 & 27.73 \\
\hline $36-45$ & 44 & 32.1 & 6-15years & 35 & 25.6 \\
\hline $46-60$ & 41 & 29.9 & 16-30years & 29 & 21.2 \\
\hline 60 above & 37 & 27.0 & many years ago & 27 & 19.7 \\
\hline Total & 137 & 100 & Total & 137 & 100 \\
\hline \multicolumn{3}{|l|}{ Marital status } & \multicolumn{3}{|c|}{ Are the bus stops serving there purposes? } \\
\hline Single & 15 & 10.9 & Yes & 78 & 56.9 \\
\hline Married & 118 & 86.1 & No & 59 & 43.1 \\
\hline Total & 137 & 100 & Total & 137 & 100 \\
\hline \multicolumn{3}{|c|}{ Which of the commercial transit do you drive? } & \multicolumn{3}{|c|}{ Which of the commercial vehicle best along this route? } \\
\hline Bus & 31 & 22.6 & Car & 84 & 61.3 \\
\hline Tricycle & 22 & 16.1 & Tricycle & 17 & 12.4 \\
\hline Car & 80 & 58.4 & Bus & 25 & 18.3 \\
\hline Motorcycle & 4 & 2.9 & Motorcycle & 11 & 8 \\
\hline Total & 137 & 100 & Total & 137 & 100 \\
\hline $\begin{array}{l}\text { Are the road properly } \\
\text { planned? }\end{array}$ & & & \multicolumn{3}{|c|}{ Are there any well-established bus stops in your route? } \\
\hline Yes & 98 & 71.5 & Yes & 73 & 53.3 \\
\hline No & 39 & 28.5 & No & 64 & 46.7 \\
\hline Total & 137 & 100 & Total & 137 & 100 \\
\hline \multicolumn{3}{|c|}{ Are you the owner of this commercial vehicle? } & \multicolumn{3}{|c|}{$\begin{array}{l}\text { If your answer is yes, is the garage serving its } \\
\text { purposes? }\end{array}$} \\
\hline Yes & 100 & 73 & Yes & 74 & 54 \\
\hline No & 37 & 27 & No & 63 & 46 \\
\hline Total & 137 & 100 & Total & 137 & 100 \\
\hline \multicolumn{3}{|c|}{ In what condition is your commercial transit? } & \multicolumn{3}{|c|}{ How often does accident occur along your route? } \\
\hline Good & 83 & 60.6 & Rarely & 84 & 61.3 \\
\hline v. good & 28 & 20.4 & very often & 41 & 29.9 \\
\hline Fair & 26 & 19 & Not at all & 12 & 8.8 \\
\hline Total & 137 & 100 & Total & 137 & 100 \\
\hline \multicolumn{3}{|c|}{ Were you taught how to drive in a driving school? } & \multicolumn{3}{|c|}{ Did your transportation route obey the rights of way? } \\
\hline Yes & 46 & 33.6 & Yes & 112 & 81.8 \\
\hline No & 91 & 66.4 & No & 25 & 18.2 \\
\hline
\end{tabular}


Assessment of Major Road Transportation Planning and Management for Commercial Transport in Urban Settlement

\begin{tabular}{|c|c|c|c|c|c|}
\hline Total & 137 & 100 & Total & 137 & 100 \\
\hline $\begin{array}{l}\text { Were you taught ir } \\
\text { regulations? }\end{array}$ & acc & to traffic & Are there any working traffi & light & our route? \\
\hline Yes & 108 & 78.8 & Yes & 17 & 12.4 \\
\hline No & 29 & 21.2 & No & 120 & 87.6 \\
\hline Total & 137 & 100 & Total & 137 & 100 \\
\hline \multicolumn{3}{|c|}{$\begin{array}{l}\text { How do you feel of the daily fee collected by the } \\
\text { NURTW daily }\end{array}$} & \multicolumn{3}{|l|}{ If yes, how many times? } \\
\hline Satisfied & 3 & 2.2 & Once & 36 & 26.3 \\
\hline Extremely satisfied & 18 & 13 & two times & 45 & 32.8 \\
\hline Dissatisfied & 35 & 25.5 & many times & 5 & 10.9 \\
\hline Extremely Dissatisfied & 54 & 39.4 & Several times & 12 & 8.8 \\
\hline So bad & 27 & 19.7 & None & 29 & 21.2 \\
\hline Total & 137 & 100 & Total & 137 & 100 \\
\hline \multicolumn{3}{|c|}{$\begin{array}{l}\text { Have you ever been involved in road accident } \\
\text { along this route? }\end{array}$} & \multicolumn{3}{|c|}{ Are the roads properly managed? } \\
\hline Yes & 64 & 46.7 & Yes & 51 & 37.2 \\
\hline No & 73 & 53.3 & No & 86 & 62.8 \\
\hline Total & 137 & 100 & Total & 137 & 100 \\
\hline $\begin{array}{l}\text { How will you rate the } \\
\text { condition of your } \\
\text { route? }\end{array}$ & & & \multicolumn{3}{|c|}{$\begin{array}{l}\text { What is the population range of people that is being } \\
\text { transport daily? }\end{array}$} \\
\hline Very good & 12 & 8.8 & Few & 34 & 24.8 \\
\hline Good & 62 & 45.3 & very few & 11 & 8 \\
\hline Fair & 53 & 38.7 & Many & 69 & 50.4 \\
\hline Poor & 10 & 7.3 & Very many & 23 & 16.8 \\
\hline Total & 137 & 100 & Total & 137 & 100 \\
\hline \multicolumn{3}{|l|}{ If yes, how many? } & \multicolumn{3}{|c|}{$\begin{array}{l}\text { How effective are the traffic control agents, if there is } \\
\text { any? }\end{array}$} \\
\hline One & 9 & 6.6 & Effective & 48 & 35 \\
\hline Two & 4 & 2.9 & highly effective & 69 & 50.4 \\
\hline Three & 2 & 1.5 & not effective & 14 & 10.2 \\
\hline None & 122 & 89.1 & none at all & 6 & 4.4 \\
\hline Total & 137 & 100 & Total & 137 & 100 \\
\hline \multicolumn{3}{|c|}{$\begin{array}{l}\text { Does the road width comply with the state } \\
\text { standard? }\end{array}$} & \multicolumn{3}{|c|}{ How will you rate traffic congestion along your route? } \\
\hline Yes & 43 & 31.4 & High & 19 & 13.9 \\
\hline No & 80 & 58.4 & fair & 75 & 54.7 \\
\hline I do not know & 14 & 10.2 & Low & 43 & 31.4 \\
\hline Total & 137 & 100 & Total & 137 & 100 \\
\hline \multicolumn{3}{|c|}{$\begin{array}{l}\text { What are the major causes of traffic congestion } \\
\text { along your route? }\end{array}$} & \multicolumn{3}{|c|}{ How many bus stops are along your route? } \\
\hline illegal parking & 52 & 38 & $1-2$ & 10 & 7.3 \\
\hline $\begin{array}{l}\text { insufficient bus stops } \\
\text { space }\end{array}$ & 46 & 33.6 & up to 5 & 34 & 24.8 \\
\hline $\begin{array}{l}\text { too many pedestrian } \\
\text { crossing }\end{array}$ & 39 & 28.5 & Many & 93 & 67.9 \\
\hline Total & 137 & 100 & Total & 137 & 100 \\
\hline \multicolumn{3}{|c|}{$\begin{array}{l}\text { Is your bus stop/garage a standard one or partially } \\
\text { established? }\end{array}$} & \multicolumn{3}{|c|}{ What do you feel is the problem facing road transport? } \\
\hline Standard & 48 & 35 & traffic management & 71 & 51.8 \\
\hline partially established & 52 & 38 & bad roads & 50 & 36.5 \\
\hline not at all & 37 & 27 & $\begin{array}{l}\text { disobedient to traffic } \\
\text { regulations }\end{array}$ & 16 & 11.7 \\
\hline Total & 137 & 100 & Total & 137 & 100 \\
\hline
\end{tabular}

Generally, from Table 5 above, the results showed the analysis of response based on questionnaire to the transporters' and it showed that out of 137 respondents, the total number of transporters' using car as commercial transit was $80(58.4 \%)$ while $40(29.2 \%)$ respondents are using buses while other share the remaining $17(12.4 \%) .124(90.5 \%)$ out 137 of the transporters are licensed while only $13(9.5 \%)$ 
are not licensed. $100(73 \%)$ out of 137 of the respondents are owners of the commercial transit they drive while the remaining $37(27 \%)$ are from other source. $83(60.6 \%)$ of the respondent's vehicle condition was good while only $28(20.4 \%)$ was in a very good condition and the total number of 26 $(19 \%)$ of the respondent's vehicle was in a fair condition. 91 (66.4\%) out of 137 respondents were not taught driving in a driving school while only $46(33.6 \%)$ were taught in a driving school. $98(71.5 \%)$ out of 137 agreed that the roads are properly planned while 39 (28.5\%) disagreed. 51 (37.2\%) agreed that the roads are properly managed while $86(62.8)$ disagreed.

It also showed from the questionnaire analysis that 108 (78.8\%) out of 137 of respondent were taught driving in accordance to traffic regulations while 29 (21.2\%) were not. 54 (39.4\%) out of 137 feel extremely dissatisfied, paid to the NURTW, 35 (25.5) feel so bad, 18 (13\%) feel extremely satisfied while only $3(2.2 \%)$ feel satisfied. $38(27.7 \%)$ out 137 of the respondents have been in commercial vehicle transport for 1-5years, $35(25.5 \%)$ for 6-15years, 29 (21.2\%) for 16-30years, 27 (19.7\%) for many years ago while only $8(5.8 \%)$ are less than a year in the commercial vehicle transport. 64 $(46.7 \%)$ of the respondents had been involved in road accident and $73(53.3 \%)$ had never for once involved. $62(45.3 \%)$ respondents rated the condition of their route to be good, 53 (38.7\%) rated it to be fair, $12(8.8 \%)$ rated it very good and only $10(7.3 \%)$ respondents rated it poor. $86(62.8 \%)$ respondents agreed that roads are properly managed in their area and $51(37.2 \%)$ disagreed. 120 (87.6\%) out of 137 said there is no working traffic lights along their transport route and only 17 (12.4\%) respondents have it working along their routes $112(81.8 \%)$ out of 137 respondents agreed that their transportation route obey the right of ways and $25(18.2 \%)$ disagreed. $43(31.4 \%)$ respondents said the road width comply with the state standard, 80 (58.4\%) said No and 14 (10.2\%) said I do not know. Population range of people that's being transport daily from garages to their destination varies as $69(50.4 \%)$ respondents said they are many, 34 (24.8\%) said few, 11 (8\%) said very few and $23(16.8 \%)$ said they are very many. $84(61.3 \%)$ out of 137 respondents said the best vehicle for commercial transport is car, $25(18.2 \%)$ said buses, $17(12.4 \%)$ said tricycle and only 11 $(8 \%)$ respondents said motorcycle. $97(70.8 \%)$ respondents said the traffic control agent is highly effective, $29(21.2 \%)$ said not effective and $11(8 \%)$ said there's none along their transportation route.

Moreover, 43 (31.4\%) respondents agreed that traffic congestion rate is low, 75 (54.7\%) agreed that it is fair and $19(13.9 \%)$ agreed that it is high. Furthermore, $52(38 \%)$ respondents agreed that the major causes of traffic congestion include illegal parking, 46 (33.6\%) said it is majorly caused by insufficient bus stop spaces and $39(28.5 \%)$ said too many pedestrian crossing is also a major cause of traffic congestion. 48 (35\%) out of 137 of the respondents said their garages is standard, $52(38 \%)$ said partially established and $37(27 \%)$ respondents said Not at all. $74(54 \%)$ respondents said their garages are really serving their purposes while $63(46 \%)$ said Not at all. $73(53.3 \%)$ respondents said their bus stops are well established and $64(46.7 \%)$ said they are not. $93(67.9 \%)$ respondents said there are many bus stops along their route, $34(24.8 \%)$ said they are up to 5 while only $10(7.3 \%)$ respondents said it is 1-2 and of the established bus stops, 78 (57\%) respondents said the bus stops are serving their purpose while $59(43 \%)$ said No. 84 (61.3\%) out of 137 said accident rarely occur in their transportation route, $41(29.9 \%)$ said it is often while $12(8.8 \%)$ respondents said accident don't happen at all. $71(51.8 \%)$ out of 137 respondents said traffic management is the major problem facing road transport, $50(36.5 \%)$ said it is bad roads and only $16(11.7 \%)$ respondents said it is disobedient to traffic regulations. It can be deduced from the results generated from the transporter response that transportation are not properly plan and managed and to eradicate or reduce these problems; there must be adequate garages and bus stops, proper drainages, road width should be enlarge, all dilapidated roads that require attention should be rehabilitated, public enlightenment, traffic education, close all illegal shops built along the right of way, creating alternative routes for heavy vehicles, provision for pedestrian facilities, proper training of traffic personnel, prohibit all form of hawking or trading on the road, reduce the number of bus stops where necessary.

Table 6. Result of the Analysis of Questionnaire Designed for Passengers

\begin{tabular}{|l|l|l|l|l|l|}
\hline Sex & Frequency & Percentage & $\begin{array}{l}\text { How will you rate the driving of the } \\
\text { commercial vehicle drivers along this route? }\end{array}$ & Frequency & Percent \\
\hline Male & 119 & 51.1 & Reckless & 67 & 28.8 \\
\hline Female & 114 & 48.9 & Careful & 166 & 71.2 \\
\hline Total & 233 & 100 & Total & How will you rate the condition of the commercial vehicles in this garage? \\
\hline
\end{tabular}


Assessment of Major Road Transportation Planning and Management for Commercial Transport in Urban Settlement

\begin{tabular}{|c|c|c|c|c|c|}
\hline \multicolumn{3}{|c|}{ Educational Qualification } & Good & 85 & 36.5 \\
\hline Primary & 13 & 5.6 & Fair & 126 & 54.1 \\
\hline Secondary & 61 & 26.2 & Poor & 22 & 9.4 \\
\hline Tertiary & 73 & 31.3 & Total & 233 & 100 \\
\hline Graduate & 63 & 27.0 & \multicolumn{3}{|c|}{$\begin{array}{l}\text { Are there any traffic control like traffic lights, traffic warder along this } \\
\text { route? }\end{array}$} \\
\hline $\begin{array}{l}\text { Post } \\
\text { graduate }\end{array}$ & 16 & 6.9 & Yes & 105 & 45.1 \\
\hline None & 7 & 3.0 & No & 128 & 54.9 \\
\hline Total & 233 & 100 & Total & 233 & 100 \\
\hline \multicolumn{3}{|l|}{ Age Group } & \multicolumn{3}{|c|}{ If yes, are they effective? } \\
\hline $18-25$ & 90 & 38.6 & Yes & 96 & 41.2 \\
\hline $26-35$ & 65 & 27.9 & No & 137 & 58.8 \\
\hline $36-45$ & 39 & 16.7 & Total & 233 & 100 \\
\hline $46-60$ & 22 & 9.4 & \multicolumn{3}{|c|}{ Do you think there are enough commercial vehicles in this area? } \\
\hline 60 above & 17 & 7.3 & Yes & 183 & 78.5 \\
\hline Total & 233 & 100 & No & 50 & 21.5 \\
\hline \multicolumn{3}{|l|}{ Marital status } & Total & 233 & 100 \\
\hline Single & 128 & 54.9 & \multicolumn{3}{|c|}{ How will you rate the effectiveness of the commercial vehicle in this area? } \\
\hline Married & 96 & 41.2 & Satisfied & 136 & 58.4 \\
\hline \multirow[t]{2}{*}{ Widow } & 9 & 3.9 & Dissatisfied & 58 & 24.9 \\
\hline & & & extremely satisfied & 23 & 9.9 \\
\hline Total & 233 & 100 & extremely dissatisfied & 11 & 0.5 \\
\hline \multicolumn{3}{|c|}{$\begin{array}{l}\text { What is your means of transportation along } \\
\text { this route? }\end{array}$} & Total & 33 & 100 \\
\hline Car & 93 & 39.9 & \multicolumn{3}{|c|}{ How often do you use public transport? } \\
\hline Bus & 58 & 24.89 & Daily & 112 & 48.1 \\
\hline Motorcycle & 63 & 27.0 & Weekly & 41 & 17.6 \\
\hline Tricycle & 19 & 8.2 & Monthly & 15 & 6.4 \\
\hline Total & 233 & 100 & Everyday & 65 & 27.9 \\
\hline \multicolumn{3}{|c|}{$\begin{array}{l}\text { Do you feel convenient when passing } \\
\text { through this route? }\end{array}$} & Total & 233 & 100 \\
\hline Yes & 160 & 68.7 & \multicolumn{3}{|c|}{ How do you normally pay for transport fare? } \\
\hline No & 73 & 31.3 & Ticket & 18 & 7.7 \\
\hline Total & 233 & 100 & Cash & 215 & 92.3 \\
\hline \multicolumn{3}{|c|}{ Is the bus service in your area frequent? } & Online & 00 & 0.00 \\
\hline Yes & 137 & 58.8 & Total & 233 & 100 \\
\hline No & 96 & 41.2 & \multicolumn{3}{|c|}{$\begin{array}{l}\text { How many minutes/hour did you normally use along this route before } \\
\text { getting to your destination? }\end{array}$} \\
\hline Total & 233 & 100 & less than 20min. & 74 & 31.8 \\
\hline \multicolumn{3}{|c|}{$\begin{array}{l}\text { What do you feel is the major problem } \\
\text { commercial vehicle transportation is facing } \\
\text { today? }\end{array}$} & Up to $20 \mathrm{~min}$ & 57 & 24.5 \\
\hline Traffic & 122 & 52.4 & Up to $25 \mathrm{~min}$ & 46 & 19.7 \\
\hline Bus & 50 & 21.5 & Up to $30 \mathrm{~min}$ & 24 & 10.3 \\
\hline Safety & 38 & 16.3 & Up 1hour & 23 & 9.9 \\
\hline Tax & 23 & 9.9 & above 1 hour & 9 & 3.9 \\
\hline Total & 233 & 100 & Total & 33 & 100 \\
\hline \multicolumn{3}{|c|}{$\begin{array}{l}\text { Since how long have you been using } \\
\text { vehicle transport services? }\end{array}$} & \multicolumn{3}{|c|}{ Express your opinion about the attitude of the transporters? } \\
\hline $\begin{array}{l}\text { less than } 1 \\
\text { year }\end{array}$ & 30 & 12.9 & Satisfied & 28 & 12 \\
\hline $\begin{array}{l}\text { less than } 2 \\
\text { years }\end{array}$ & 25 & 10.7 & Neutral & 82 & 35.2 \\
\hline $\begin{array}{l}\text { less than } 3 \\
\text { years }\end{array}$ & 26 & 11.2 & Dissatisfied & 90 & 38.6 \\
\hline \multirow[t]{2}{*}{$\begin{array}{l}\text { more than } 3 \\
\text { years }\end{array}$} & 142 & 60.9 & extremely satisfied & 17 & 7.3 \\
\hline & & & extremely dissatisfied & 16 & 4.7 \\
\hline Total & 233 & 100 & Total & 233 & 100 \\
\hline \multicolumn{3}{|c|}{$\begin{array}{l}\text { As a road user, is this route properly } \\
\text { planned? }\end{array}$} & \multicolumn{3}{|c|}{ Have you experience any problem along this route? } \\
\hline Yes & 149 & 64.0 & Yes & 67 & 28.8 \\
\hline No & 84 & 36.1 & No & 166 & 71.2 \\
\hline Total & 233 & 100 & Total & 233 & 100 \\
\hline If yes, does & & & Are there any other ro & & \\
\hline
\end{tabular}


Assessment of Major Road Transportation Planning and Management for Commercial Transport in Urban Settlement

\begin{tabular}{|c|c|c|c|c|c|}
\hline \multicolumn{6}{|l|}{$\begin{array}{l}\text { this route } \\
\text { properly } \\
\text { managed? }\end{array}$} \\
\hline Yes & 88 & 37.8 & Yes & 158 & 67.8 \\
\hline No & 145 & 62.2 & No & 75 & 32.2 \\
\hline Total & 233 & 100 & Total & 233 & 100 \\
\hline \multicolumn{3}{|c|}{$\begin{array}{l}\text { How did you get information about } \\
\text { transport services? }\end{array}$} & \multicolumn{3}{|c|}{ If yes, would you still prefer to use any of the routes? } \\
\hline Driver & 111 & 47.6 & Yes & 129 & 55.4 \\
\hline Employer & 18 & 7.7 & No & 104 & 44.6 \\
\hline $\begin{array}{l}\text { information } \\
\text { pasted on } \\
\text { bus }\end{array}$ & 33 & 14.2 & Total & 233 & 100 \\
\hline Conductor & 35 & 15.0 & How will yo & s rout & \\
\hline Passerby & 36 & 15.5 & Good & 90 & 38.6 \\
\hline Total & 233 & 100 & very good & 22 & 9.4 \\
\hline \multicolumn{3}{|c|}{$\begin{array}{l}\text { How will you rate the traffic congestion in } \\
\text { this route? }\end{array}$} & Fair & 65 & 27.9 \\
\hline High & 93 & 39.9 & very fair & 32 & 13.7 \\
\hline Low & 127 & 54.5 & Poor & 24 & 10.3 \\
\hline Free & 23 & 9.9 & Total & 233 & 100 \\
\hline Total & 233 & 100 & \multicolumn{3}{|c|}{ Do you think transport fare increase due to traffic congestion in this route? } \\
\hline \multicolumn{3}{|c|}{$\begin{array}{l}\text { How frequently does accident occur along } \\
\text { this route? }\end{array}$} & Yes & 128 & 54.9 \\
\hline very often & 50 & 21.5 & No & 105 & 45.1 \\
\hline Rarely & 174 & 74.8 & Total & 233 & 100 \\
\hline Constantly & 9 & 3.9 & \multicolumn{3}{|c|}{ Which commercial vehicle do you think is mostly used along this route? } \\
\hline Total & 233 & 100 & Bus & 75 & 32.2 \\
\hline \multicolumn{3}{|c|}{$\begin{array}{l}\text { Do you reach your destination at } \\
\text { appropriate time? }\end{array}$} & Car & 39 & 16.7 \\
\hline Yes & 91 & 39 & Tricycle & 61 & 26.2 \\
\hline No & 142 & 61 & Motorcycle & 58 & 24.9 \\
\hline Total & 233 & 100 & Total & 233 & 100 \\
\hline
\end{tabular}

Generally, from Table 6 above, the results showed the analysis of response based on questionnaire administered to the passengers. It showed that $93(40 \%)$ out of 233 respondents uses car as a means of transportation, 58 (24.9\%) uses bus, 63 (27\%) uses motorcycle and the total number of $19(8.2 \%)$ respondents uses tricycle which implies that people prefer car than other vehicle types. $160(68.7 \%)$ out 233 felt convenient while passing through a particular route and $73(31.3 \%)$ felt inconvenient. 137 (58.8\%) respondents said the bus service in their area is frequent and $96(41.2 \%)$ said they aren't frequent. $122(52.4 \%)$ respondents are of the view that the major problem facing commercial vehicle transportation this day is traffic, $50(21.5 \%)$ said bus schedule, $38(16.3 \%)$ said safety and $23(9.9 \%)$ said it's levy/taxes which denotes that traffic was the major problem facing commercial transportation. 149 (64\%) of the road users out of 233 said the roads are properly planned and 84 (36\%) disagreed. $145(62.2 \%)$ respondents out of 233 said the roads are not well managed and 88 (37.8\%) agreed. $90(38.6 \%)$ out of 233 respondents rated the condition of roads along their route to be in good condition, $22(9.4 \%)$ said it is very good, 65 (27.9\%) said it is fair, 32 (13.7\%) said it is very fair and $24(10.3 \%)$ said the condition is very bad which implies that the road are managed. 127 (54.5\%) out 233 respondents said the level of traffic congestion is low, 93 (39.9\%) said it is high and only $23(9.9 \%)$ said it is free.

Moreover, the result also showed that there is always increment in Transport fare whenever there is traffic congestion as $128(54.9 \%)$ respondents agreed and $105(45.1 \%)$ disagreed. $174(74.8 \%)$ out of 233 said accident rarely occur in their route, $50(21.5 \%)$ said it often happened and only $9(3.9 \%)$ said it constantly happen. $75(32.2 \%)$ respondents out of 233 said bus is mostly used along their route, 39 (16.7\%) said it is car, $61(26.2 \%)$ said it is tricycle and 58 (24.9) said it is motorcycle. $126(54.1 \%)$ out of 233 respondents rated the commercial vehicles condition fair, $85(36.5 \%)$ said it is good and only $22(9.4 \%)$ rated their condition to be poor which means that all commercial vehicle need to be in good order. $166(71.2 \%)$ respondents out of 233 rated the driving of the commercial vehicle drivers as careful and $67(28.8 \%)$ said they drive recklessly. $128(52.3 \%)$ respondents said there is absence of traffic control along their route and $105(45.1 \%)$ said there is, which means that traffic control needs to be place at affected areas. $137(58.8 \%)$ out of 233 said the traffic controls are not effective while 
Assessment of Major Road Transportation Planning and Management for Commercial Transport in Urban Settlement

only $96(41.2 \%)$ respondents said they are. $183(78.5 \%)$ respondents agreed that there is enough commercial vehicles within the study area while $50(21.5 \%)$ disagree. $215(92.3 \%)$ respondents said they pay by cash, none (0\%) said they pay online and only 18 (7.7\% pay using ticket. $74(31.8 \%)$ out of 233 respondent said they usually spend less than $20 \mathrm{mins}$ before getting to their destination, 57 (24.5\%) said it took them up to 20mins, $46(19.7 \%)$ said they spend up to $25 \mathrm{mins}, 24(10.3 \%)$ said they spend up to 30mins, 23 (9.9\%) said they spend up to an hour and only $9(3.9 \%)$ respondents said they spent above an hour. $166(71.2 \%)$ out of 233 respondents said they've never experience any problem along their routes and the total number of $67(28.8 \%)$ respondents said they've experienced problems along their route. $158(67.8 \%)$ respondents said there are other routes linking to their destination while $75(32.2 \%)$ said there are no other routes linking to their destination.

Table7. Result of analysis of Travel Time and Speed estimation by vehicles

\begin{tabular}{|l|l|l|l|l|l|l|}
\hline $\begin{array}{l}\text { From } \\
\text { Location }\end{array}$ & $\begin{array}{l}\text { To } \\
\text { Location }\end{array}$ & \multicolumn{6}{|l|}{ Approximate Travel Time by Vehicles in minutes and Speed in km/h } \\
\hline & & Car & Buses & Tricycle & Motorcycle & Average Speed Estimation $(\mathrm{km} / \mathrm{h})$ \\
\hline Sango & Ojoo & 8 & 12 & 12 & 6 & $20-70$ \\
\hline Ojoo & Mokola & 20 & 23 & 25 & 15 & $20-65$ \\
\hline Sango & Eleyele & 15 & 20 & 20 & 10 & $25-80$ \\
\hline Mokola & Gate & 10 & 15 & 15 & 10 & $20-60$ \\
\hline Gate & UI & 20 & 20 & 23 & 13 & $20-60$ \\
\hline Sango & Beere & 18 & 25 & 13 & 18 & $25-65$ \\
\hline Gate & Bashorun & 10 & 15 & 27 & 7 & $20-65$ \\
\hline
\end{tabular}

The shorter the distance travelled by vehicles, the shorter time taken per minutes/hour and the lower the speed used to reach destination. The longer the journey embarks upon, the longer the distance travel per time taken. Though, in some places along the same route, speed differs. From Table 7 above shows that the travel time and the speed used by vehicle varied from destination to destination. Within the study area, the travel time for car ranges between $8-20 \mathrm{mins}, 12-23 \mathrm{mins}$ by buses, $12-27 \mathrm{mins}$ by tricycle, 6-18minutes by motorcycle and this is due to the narrow passage use by the rider. The average speed estimate for the journey ranges from $20-80 \mathrm{~km} / \mathrm{hr}$ within the study area but varied from location to location.

Table8. Result of analysis of Cost of transport within the study area

\begin{tabular}{|c|c|c|c|c|c|}
\hline Garage & Destination & Car (\#) & Buses (\#) & Tricycle (\#) & Motorcycle (\#) \\
\hline Sango & Ojoo & 80 & 70 & 70 & 100 \\
\hline Sango & Beere & 100 & 80 & 80 & 150 \\
\hline Sango & Oje & 100 & 80 & 80 & 150 \\
\hline Sango & Mokola & 50 & 30 & 50 & 70 \\
\hline Sango & Eleyele & 50 & 50 & 50 & 100 \\
\hline Sango & Agbowo/ UI & 50 & 30 & 50 & 100 \\
\hline Sango & Gate & 80 & 70 & 80 & 100 \\
\hline Sango & Bodija & 50 & 50 & 50 & 50 \\
\hline \multicolumn{6}{|c|}{ Cost of transport from Bodija } \\
\hline Bodija & Ojoo & 70 & 50 & 70 & 100 \\
\hline Bodija & Oje & 100 & 70 & 70 & 150 \\
\hline Bodija & Beere & 100 & 80 & 80 & 150 \\
\hline Bodija & Ashi Junction & 50 & 50 & 50 & 100 \\
\hline Bodija & Mokola & 50 & 50 & 50 & 150 \\
\hline Bodija & Eleyele & 100 & 100 & & 200 \\
\hline Bodija & Sango & 50 & 50 & 50 & 70 \\
\hline \multicolumn{6}{|c|}{ Cost of transport from Mokola } \\
\hline Mokola & Sango & 50 & 50 & 50 & 100 \\
\hline Mokola & Gate & 50 & 50 & 50 & 100 \\
\hline Mokola & Ojoo & 100 & 80 & 100 & 150 \\
\hline Mokola & Bodija & 50 & 50 & 50 & 150 \\
\hline \multicolumn{6}{|c|}{ Cost of transport from Gate } \\
\hline Gate & Bashorun & 70 & 50 & 70 & 100 \\
\hline Gate & UI & 100 & 80 & 80 & 150 \\
\hline Gate & Mokola & 50 & 50 & 50 & 100 \\
\hline
\end{tabular}


Assessment of Major Road Transportation Planning and Management for Commercial Transport in Urban Settlement

\begin{tabular}{|c|c|c|c|c|c|}
\hline Gate & Beere & 50 & 50 & 50 & 70 \\
\hline Gate & Sango & 80 & 70 & 80 & 100 \\
\hline \multicolumn{6}{|c|}{ Cost of transport from Beere } \\
\hline Beere & Gate & 50 & 50 & 50 & 70 \\
\hline Beere & Bodija & 100 & 80 & 80 & 150 \\
\hline Beere & Sango & 100 & 80 & 80 & 150 \\
\hline
\end{tabular}

Cost of transport can be determined by the vehicle type, and also the distance travel from one place to the other can be determined by vehicle cost. From the Table 8 above, the cost of car ranges from \#50 $\# 100$, buses ranges from \#30-\#100, tricycle ranges from \#50 - \#100 and bicycle ranges from \#50 $\# 150$. Though, the cost varied from garages/bus stops to destination.

Table9. Result of population of people transported daily by vehicles per garages

\begin{tabular}{|l|l|l|l|l|l|}
\hline $\begin{array}{l}\text { Name } \\
\text { of } \\
\text { Garage }\end{array}$ & $\begin{array}{l}\text { No. Transported } \\
\text { Daily by Cars }\end{array}$ & $\begin{array}{l}\text { No. Transported } \\
\text { Daily by Buses }\end{array}$ & $\begin{array}{l}\text { No. Transported } \\
\text { Daily by Tricycles }\end{array}$ & $\begin{array}{l}\text { No. Transported } \\
\text { Daily by Motorcycles }\end{array}$ & Total \\
\hline Sango & 9,555 & 5,432 & 1,680 & 24,990 & 41,657 \\
\hline Bodija & 30,150 & 10,990 & 7,752 & 16,250 & 65,142 \\
\hline Beere & 4,125 & 9,800 & 13,580 & 19,520 & 47,025 \\
\hline Gate & 5,720 & 2,814 & 2,940 & 42,000 & 53,474 \\
\hline Mokola & 16,800 & 2,250 & 15,600 & 33,300 & 67,950 \\
\hline Total & $66,350(24 \%)$ & $31,286(11.4 \%)$ & $41,552(15 \%)$ & $136,060(49.6 \%)$ & 275,248 \\
\hline
\end{tabular}

Source: Authors Field Survey 2019

For the purpose of this study, population was calculated using manual counting of passengers per vehicle trip. Table 9 above showed that a total population of two hundred and seventy five thousands, two hundred and forty eight $(275,248)$ persons is migrating daily from one location to the other within the study area. The table reveals that the total population transported daily by motorcycle is higher with $(49.6 \%)$ than other vehicle types and this may be due to the fastness in such a way that motorcycle will always find their way in case of congestions.

Table10. Result of Manual Counting of Vehicles per bus stops and garages

\begin{tabular}{|l|l|l|l|l|l|}
\hline $\begin{array}{l}\text { Name of } \\
\text { Garage }\end{array}$ & $\begin{array}{l}\text { No. of } \\
\text { Cars }\end{array}$ & No. of Buses & No. of Tricycle & No. of Motorcycle & Total \\
\hline Sango & 273 & 97 & 70 & 357 & 797 \\
\hline Bodija & 402 & 157 & 114 & 325 & 998 \\
\hline Beere & 55 & 70 & 97 & 305 & 527 \\
\hline Gate & 230 & 67 & 145 & 701 & 1,143 \\
\hline Mokola & 280 & 25 & 130 & 555 & 990 \\
\hline Total & 1240 & 416 & 556 & 2243 & 4,455 \\
\hline
\end{tabular}

From Table 10 above, a total of four thousand, four hundred and fifty five $(4,455)$ vehicles with 1,240 $(27.8 \%)$ cars counted, $416(9.3 \%)$ buses counted, $556(12.5 \%)$ tricycles counted, and $2243(50.4 \%)$ motorcycles counted within the study area. It means that people are using motorcycle within the study area than other vehicle types. Bodija has the highest number of car and buses with a total of 402 car/cab and 157 buses and this is due to the standard garages and bus stops in the area. Gate has the highest number of tricycles and motorcycles with a total of 145 tricycles and 701 motorcycles and this may be due to factor such as the university teaching hospital (UCH), Ibadan North local government headquarters, industrial training fund office etc located along the route to mokola. People prefer the two vehicle types because they are faster in terms of reaching destination quickly than other vehicle types

Table 11. Result of Number of Traffic Lights, Coordinates $x$, $y$ and their Conditions

\begin{tabular}{|l|l|l|l|l|}
\hline Location & No. of Traffic Light & Easting (m) & Northing $(\mathbf{m})$ & Condition \\
\hline Sango & 4 & 599174.138 & 820650.560 & Bad \\
\hline Premier Junction & 3 & 598519.261 & 819329.299 & Bad \\
\hline Mokola & 4 & 598479.968 & 819333.271 & Bad \\
\hline Total Garden & 4 & 600318.586 & 817873.686 & Fair \\
\hline Secretariat Junction & 3 & 598992.787 & 818232.037 & Good \\
\hline
\end{tabular}


Assessment of Major Road Transportation Planning and Management for Commercial Transport in Urban Settlement

\begin{tabular}{|l|l|l|l|l|}
\hline $\begin{array}{l}\text { Governor's House } \\
\text { Junction }\end{array}$ & 4 & 598519.261 & 819329.299 & $\mathrm{Bad}$ \\
\hline Iyana Housing & 3 & 598948.634 & 820211.587 & $\mathrm{Bad}$ \\
\hline Total & 25 & & & \\
\hline
\end{tabular}

Table 11 above showed a total number of 25 traffic lights within the study area. Generally, the number shows that only three (3) in Secretariat Junction was in good working condition and active, four (4) in total garden was fair condition and partially functioning while others in Sango, Premier Junction, Mokola, Governors house Junction and Iyana housing are all in bad condition and requires either renovation or new ones so as to easy flow of vehicles and route free of congestion. Generally, seven (7) are seen working be it good or fair in condition.

Table12. Result of Road width in the Study Area

\begin{tabular}{|l|l|l|l|l|l|l|l|}
\hline Road Name & Numbers of lanes & Width & Specificatior & Setback & Length $(\mathbf{m})$ & Perimeter $(\mathbf{m})$ & Area $\left(\mathbf{m}^{2}\right)$ \\
\hline Ojoo/Mokola & 2 & 11 & Major & $5-15$ & $7,216.397$ & $13,940.258$ & $1,846,097.645$ \\
\hline Bodija/Secretaria & 2 & 9 & Major & $5-15$ & $3,884.712$ & $7,319.968$ & $811,388.980$ \\
\hline Secretariat/Total & 2 & 9 & Major & $7-15$ & $1,167.870$ & $2,281.258$ & $31,878.526$ \\
\hline Total Garden/Ga & 2 & 9 & Major & $3-15$ & $1,209.560$ & $2,374.099$ & $86,104.220$ \\
\hline Gate/Beere & 2 & 8 & Major & $3-15$ & $2,817.998$ & $5,611.004$ & $275,015.630$ \\
\hline Gate/Bashorun & 2 & 11 & Major & $3-15$ & $3,740.147$ & $7,404.183$ & $431,983.400$ \\
\hline Beere/Total Garc & 2 & 8 & Major & $3-15$ & $2,765.395$ & $5,068.586$ & $278,813.509$ \\
\hline $\begin{array}{l}\text { Total } \\
\text { Garden/Mokola }\end{array}$ & 2 & 10 & Major & $5-12$ & $2,162.074$ & $4,232.066$ & $82,528.461$ \\
\hline
\end{tabular}

From the result of the road width from Table 12 above, all the routes measured did not conform with the $14 \mathrm{~m}$ road width state guidelines and this may be due to reason that all these route were all in a singlle lane before converting them two lanes which also affects their setback to conform.

Figure 6 presents the bus stops location within the study area, and shows the location of standard garages and sub-garages. Figure 9 presents the location of T-Junction (Intersections) and Traffic light. Moreover, figure 10 presents generalised map and buffering zone map within the study area.

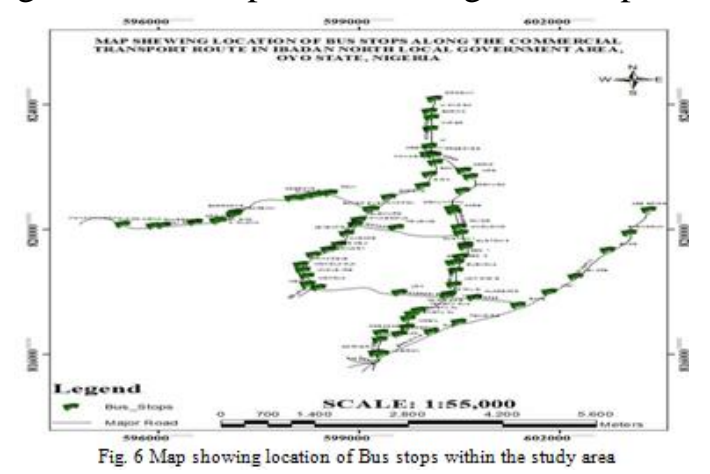

From figure 6, 72 bus-stops were in the Local government. It showed that the bus stops are clustered together which denotes that they are not far from one another and this may lead to incessant parking of vehicle along the road

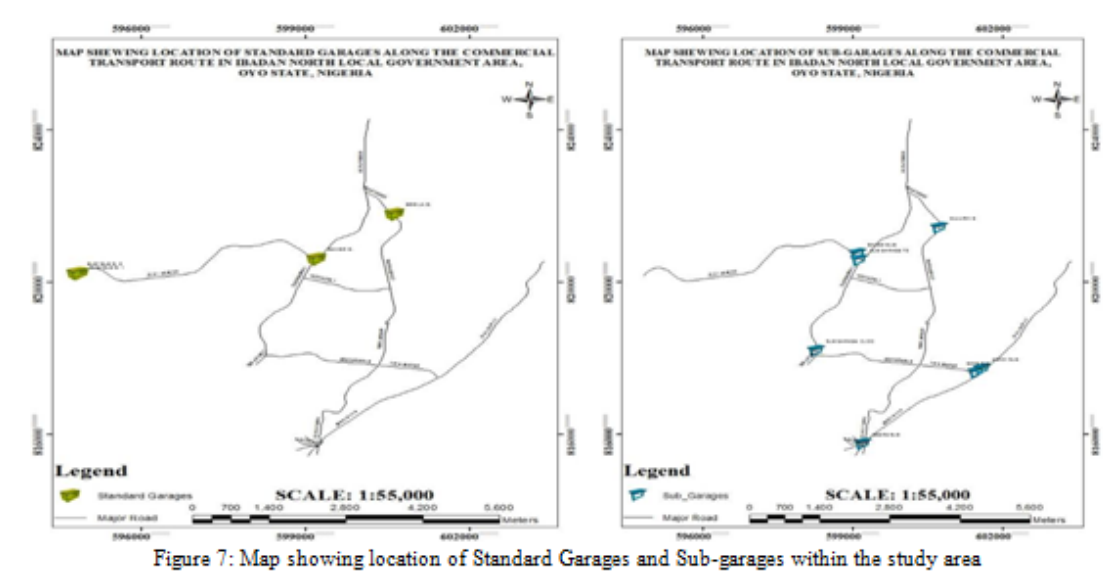


Figure 7 above showed that only three (3) well established garages present in the local Government and are situated at Bodija, Sango and Eleyele. Therefore, the larger percentage of the garages in the study area is regarded as illegal.

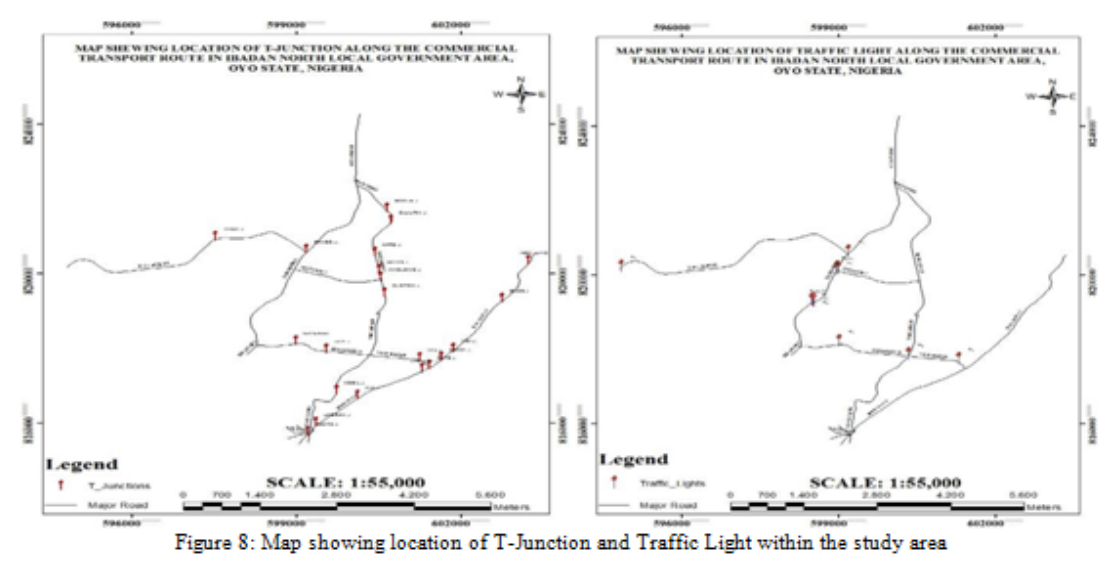

From Figure 8 above, the local Government has 21 Intersection junctions and most of the intersection junctions in the study area are properly planned. Likewise, 25 Traffic lights with only nine (9) functioning which showed that the majority of the traffic light in the study area are not in good condition.

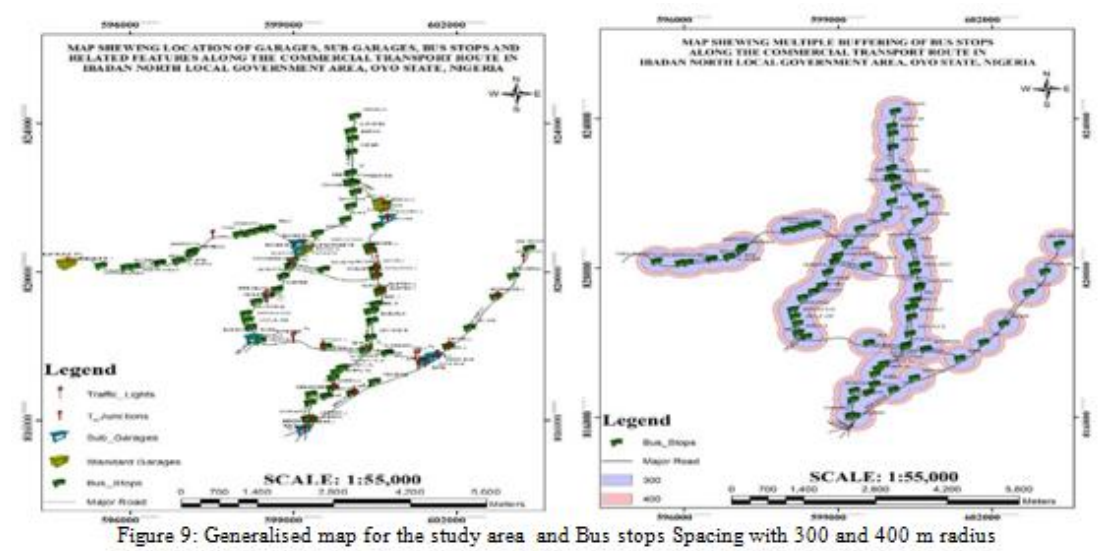

The composite map showing the result of the field information acquired and the proximity/nearness of one bus stop to another was done to determine the spacing of bus stops within the study area (figure 9). Multiple buffering analyses with a distance of $300 \mathrm{~m}$ and $400 \mathrm{~m}$ in accordance with UITP Guidance on Bus Stop Spacing (International Association of Transport Planning) and this was based on the standard space that should be in between the bus stops in the city and urban areas (Table 13).

Table13. UITP Guidance on Bus Stop Spacing

\begin{tabular}{|l|l|l|}
\hline Utilization & $\begin{array}{l}\text { Stop } \\
\text { spacing }\end{array}$ & $\begin{array}{l}\text { Average walking time (at } \\
\mathbf{7 5 m} / \mathbf{m i n} \text { ) }\end{array}$ \\
\hline $\begin{array}{l}\text { City area, central commercial, service, administration, } \\
\text { conventional activities }\end{array}$ & $300 \mathrm{~m}$ & $4 \mathrm{~min}$ \\
\hline $\begin{array}{l}\text { Urban areas with high density residential areas, commercial } \\
\text { activities, educational sites }\end{array}$ & $400 \mathrm{~m}$ & $6 \mathrm{~min}$ \\
\hline Urban areas with low density, residential area & $600 \mathrm{~m}$ & $8 \mathrm{~min}$ \\
\hline
\end{tabular}

Source: UITP (International Association of Transport Planning)

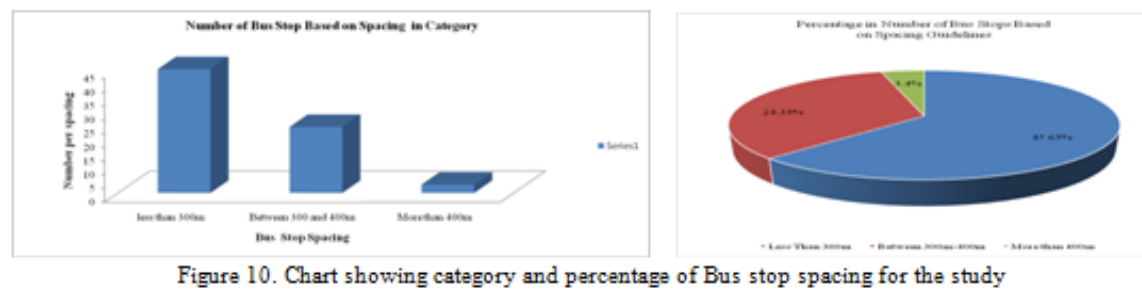


Assessment of Major Road Transportation Planning and Management for Commercial Transport in Urban Settlement

Table14. Results of Bus stops spacing in the study area

\begin{tabular}{|l|l|}
\hline Bus stop spacing & No of Bus stops \\
\hline Less Than $300 \mathrm{~m}$ & 45 \\
\hline Between $300 \mathrm{~m}-400 \mathrm{~m}$ & 24 \\
\hline More than $400 \mathrm{~m}$ & 03 \\
\hline
\end{tabular}

From Table 14 above, it implies that 3 bus stops (4\%) of 72 bus stops are located at over $400 \mathrm{~m}$ to another bus stop, Though this will be satisfactory with the cab drivers as they will get to speed up a bit at that period but unfortunately, the passengers has to walk over $6 \mathrm{~min}$ of time to get to the nearest bus stop. Also, only 24 bus stops (33\%) are within the UITP specification, this implies that the drivers can move at a reasonable speed and as well the passengers walking at a maximum distance of $6 \mathrm{~min}$. likewise, $45(62.5 \%)$ bus stops are at less than $300 \mathrm{~m}$ to the next bus stop, this consumes fuel as the driver stops at little distances to each other and also the driver will be travelling at an extremely low speed which will eventually increase travel time as well. Although, the passengers have to walk at a lesser distances to the bus stop.

\subsection{Spatial Search and Query}

Spatial search is used in GIS to search for particular area of interest within a neighborhood, which must be logically defined. It is used in the processing and manipulation of data to generate required information. While spatial query is the method of retrieving data that are part of GIS database. The queries performed to give answer to few generic questions that were asked from the database which were made possible due to the implicit linkage of the graphic and attribute data in ArcGIS 10.2.1. The results of the query were all displayed.
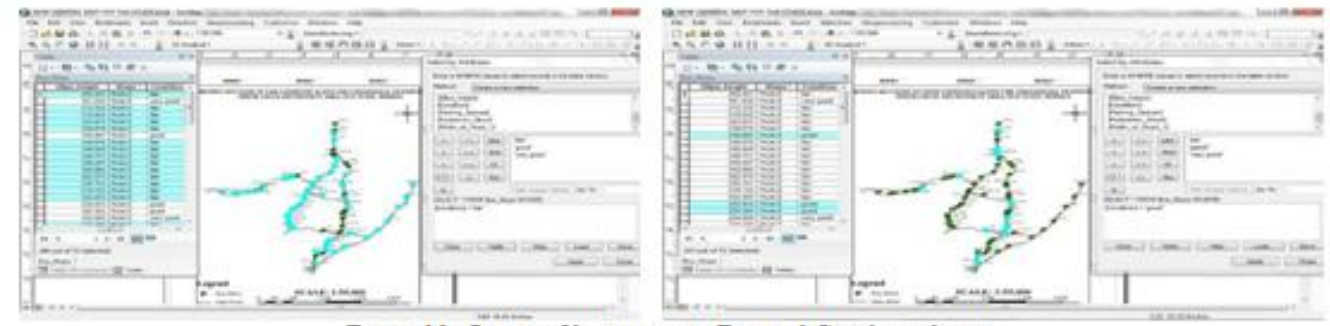

Figure 11. Query of bus stops in Fair and Good condition.

Query in figure 11 was performed to locate the condition of bus stops in the study area and the result shows that 49 out of the 72 bus stops are fair in condition while 14 out of the 72 bus stops are in good condition within the study area.
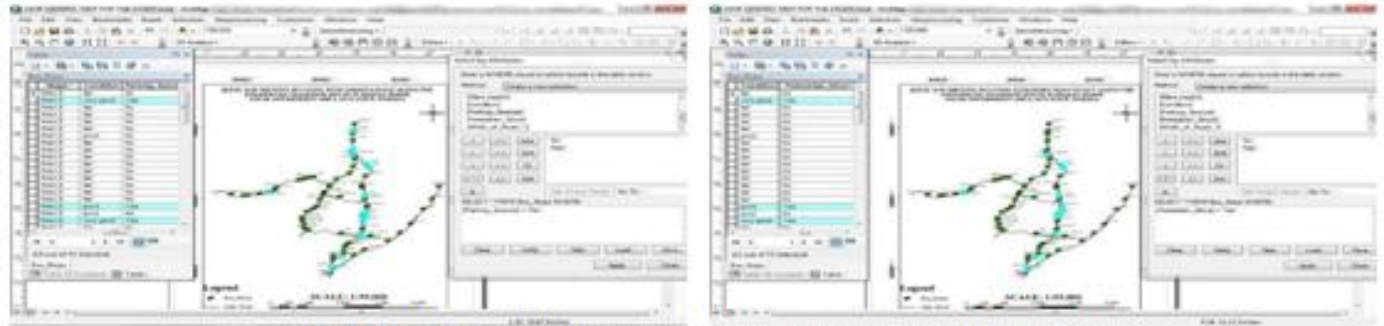

Figure 12. Query of bus stops with parking space and pedestrian sit-out

Figure 12 showed query to locate the bus stops with parking space in the study area and the result shows that only 15 out of the 72 bus stops has parking space while the bus stops with pedestrian sitout in the study area showed that only 12 out of the 72 bus stops has pedestrian sit-out.

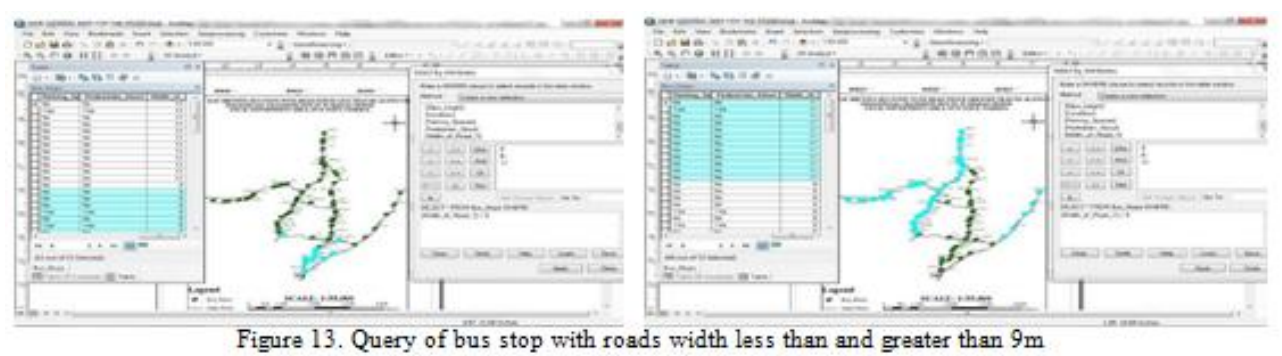


From figure 13, query was performed to determine the bus stop with roads width less than $9 \mathrm{~m}$ width in the study area and the result shows that 12 out of the 72 bus stop have road width less than $9 \mathrm{~m}$ which implies that the roads were not properly planned while bus stops with road width greater than $9 \mathrm{~m}$ and the showed that 40 out of the 72 bus stop are with road width greater than $9 \mathrm{~m}$ which implies that the roads were not properly planned.

\section{CONCLUSION}

The application of GIS has helped in the proper assessment of commercial road transportation planning and management in Ibadan North Local Government Area. For a metropolis or parts of metropolis like the study area or a municipal and districts planning, transportation planning is one of the major and important part of managing the growth and change of such environment. With road classification systems, transportation master plans, land use guidelines and asset management plans; transportation system will be successful within a particular locality, state, region or county. The impact of transportation and professional land-use planner in any transportation planning process is very crucial in the transportation system. From the findings of the study, it was discovered that there are no sufficient standard garages and well established bus stops and likewise majority of the bus stops are not up to standard because larger percentage of them lack pedestrian sit out and parking space which mostly led to Roadside parking leading to accidents, traffic congestion among others. It was also discovered that most of the transportation routes lack working traffic lights. The study has found out that the bus stops are too close to one another which made it difficult for the government to manage. The study has also been able to iterate the fact that traffic congestion occurs mostly at road intersection due to lack of traffic control agents as well as traffic light. Some of problems associated with transportation planning and management in the study area can be attributed to inadequate physical planning and inability to adequately manage and control the commercial transport by the local and the state government.

\section{RECOMMENDATIONS}

Author recommends that Oyo State Ministry of transport, Ministry of works, Oyo State Road Transport management agency should be part of commercial road transportation process, all subgarages, bus stops that that did not obey the setback specification to the road should be relocated because some bus stop are less than I $m$ to the road, traffic control system should be improved by the government. Also, government should provide more standard garages and bus stops since only three standard garages exist while some bus stops also are not up to standard within the study area. There should be maintenance and construction of infrastructural projects, government should work hand in hand with National Union of Road Transport Workers (NURTW) to manage the commercial road transport and promote smarter travel and advance greater sustainability in passenger travel and freight transport. In the area of commercial vehicles condition, all transporters should make their vehicle to function. Government should look into the fee paid by the commuters to the NURTW so that its effects will not bounce back on people and also reorganize the union. Lastly, To properly manage the transportation infrastructure, there is need for the government to reposition the infrastructure of the study area as well as the entire state as a whole, and also, the both local and state transport sector should look into the crises that has been arises due to inadequate planning, dilapidated infrastructure, poor management and control.

\section{ACKNOWLEDGEMENTS}

Author acknowledges the support of the following people; Gbanigbani Badmus, Fijabi Oyindamola, Alade Bolaji, Adeniran Bukola, Ajayi Tosin, Esesumokhai Joseph, Oluokun Olaide, John Peter O., Elusoji Samson and Jolaoso Gbemi for their immense effort during the field data acquisition

\section{REFERENCES}

[1] Arun C., Mehta (2004). Projections of Population and Enrolment - Education for all in Indian. Module on enrolment and population projections. pp1-34. Available at: http://www.educationforallinindia.com.

[2] Bailey, L. Mokhtarian, P. L. and Little, A. (2008). The Broader Connection between Public Transportation, Energy Conservation and Greenhouse Gas Reduction. Report prepared as part of TCRP Project J-11/ Task 3 Transit Cooperative Research Program, Transportation Research Board submitted to American Public Transportation Association in http://www.apta.com/research/info/online/land_use.cfm\#i, accessed 17 April 2008. 
[3] Berry, B. J. L. Garrison, W. L. (1958). The functional bases of the central-place hierarchy. Econ. Geogr. 34(Apdl):145-154.

[4] Berry, B. J. L. Horton, F. E. (1970). Geographic Perspectives on Urban Systems. Englewood Cliffs, NJ: Prentice-Hall, 1970.

[5] Didigwu, A.U.S (2010). Transportation Problems in Nigeria Cities: Issues, Options and Solutions. International Journal of Architecture and Built Environment. Vol. 2, Number 1, Blackwell Educational Books, Yaba Lagos.

[6] Didigwu Augustus U.S and Fasina Olajide (2015). Needs for transportation planning and management in Nigeria using geographic information system. International Journal of Geography and Regional Planning Research Vol.1, No.2, pp.9-20, Published by European Centre for Research Training and Development UK (www.eajournals.org)Federal

[7] Highway Design. Washington, D. C: FHWA, USDOT.

[8] Feng xie and David Levison (2006). Measuring the structure of road networks. Geography Analysis.

[9] Goldberg, M. A. (1970). Transportation, Urban Land Values, and Rents: A Synthetic Land Economics", 46, 2 (May), 153-162.

[10] Gupta, P. Jain, N. Sikdar, P.K. and Kumar, K. (2003). Geographical Information System in https://ruralroads.org/road-transport.

[11] International Public Transit Consultant. UITP (International Association of Transport Planning). Available at: www. Alanhowesworld.com/topics/planning/principle

[12] Isard, W. F. ed. (1960). Methods of Regional Analysis: Introduction to Regional Science. Cambridge, MA: MIT Press

[13] Kang-Tsung Chang (2002). Introduction to Geographic Information System.

[14] Kothar, C.R. (2004). Research methodology and techniques second revised edition". New age international publishers.

[15] Litman, T. (2015). Land Use Impacts on Transportation, Victoria Transport Policy Institute. (www. vtpi.org); at www.vtpi.org/landtravel.pdf

[16] Mannering, L. Fred, P. Walter Kilareski, S. Scott Washburn (2004). Principles of Highway Engineering and Traffic Analysis. ${ }^{\text {rd }}$ ed. NJ: John Wiley \& Sons; 170-219.

[17] Okoko E. (2006). Transportation Planning and Modelling, Millennium Publishers.

[18] Owolabi, B. O. (2016). Effects of Commercial Activities on Transportation Route in Urban Centre's in Nigeria: A Case Study of Oba Adesida Road, Akure. International Journal of Research in Environmental Science (IJRES) Volume 2, Issue 5, 2016, PP 36-52.

[19] Pred, A. R. (1974). Major Job-Providing Organizations and Systems of Cities. Washington DC: Assoc. Am. Geogr.

[20] Richardson, H. W. (1972). Urban Economics. Baltimore: Penguin, 1972.

[21] Said, M. N. and Shah, M. Z. (2008). GIS as a Supporting Tool in the Establishment of Land Use- Road Density Model in www.GIS development.net.

[22] Sutton, J. C. Cevllos, F. Faria, D. Kamler, B. Millan, L. Palmerlee, T. Sanchez, T. W. Shiffer, M. Watanabe, W. and Wiggins, W. (2004). Geographic Information Systems Applications in Transit, Transportation Research Board, Washington, DC, TCRP Synthesis 55, 2004.

[23] World fact book, Nigeria population growth rate. Central Intelligence Agency. Available at: http://www.cia.gov/library/publication/the-world-factbook, 2013.

[24] Wyatt, P. (1997). The Development of a GIS-Based Property Information for Real Estate Valuation. International Journal of Information Science 11(5), 435-450.

[25] Yago G. (1983). The Sociology of Transportation. Annual Review of Sociology, 9, 171-190.

Citation: Adewuyi Gbola Kehinde, et.al.," Assessment of Major Road Transportation Planning and Management for Commercial Transport in Urban Settlement", International Journal of Research in Environmental Science (IJRES), vol. 6, no. 2, pp. 42-58, 2020. Available: DOI: http://dx.doi.org/10.20431 /2454-9444.0602005

Copyright:@ 2020 Authors. This is an open-access article distributed under the terms of the Creative Commons Attribution License, which permits unrestricted use, distribution, and reproduction in any medium, provided the original author and source are credited. 